\title{
Effect of Different Levels of Nitrogen and Plant Growth Regulators on Lodging and Yield of Wheat (Triticum aestivum $\mathrm{L}$.)
}

\author{
Aditya Shri $^{1 *}$, Seema $^{1}$, Sushant $^{1}$ and Mahendra Singh $^{2}$ \\ ${ }^{1}$ Department of Agronomy, ${ }^{2}$ Department of Soil Science and Agricultural Chemistry, Bihar \\ Agricultural University, Sabour, Bhagalpur, India \\ *Corresponding author
}

\section{A B S T R A C T}

\section{Keywords}

Nitrogen, Plant growth regulators (PGRs),

Chlormequat chloride,

Tebuconazole, lodging

\section{Article Info}

Accepted: 28 November 2020 Available Online: 10 December 2020
The influence of rate of $\mathrm{N}$ application and PGRs on Wheat (Triticum aestivum $\mathrm{L}$.) on lodging and yield were studied under field conditions at Research Farm of, Bihar Agricultural University, Sabour in Rabi season of 2019-20. The experiment was conducted with ten treatments consisted of different nitrogen levels and growth regulators namely Chlormequat chloride and Tebuconazole applied @ $0.2 \%$ and $0.1 \%$ respectively. The obtained results indicated that grain yield, straw yield and biological yield were recorded significantly higher in treatment $\mathrm{T}_{10}$ $(150 \% \mathrm{RDF}+\mathrm{PGRs})$ statistically at par with treatment $\mathrm{T}_{7}(100 \% \mathrm{NPK})$ as compare to other treatments while harvest index was recorded maximum in treatment $\mathrm{T}_{8}(0.45)$ and $\mathrm{T}_{9}(0.45)$. PGRs effectively reduced the lodging as compared to the same in which no PGRs had applied, however in control no lodging was observed.

\section{Introduction}

Wheat the most imported rabi crops consisted first position among the world's food crops in terms of cultivated area $(215.24 \mathrm{~m}$ ha $)$, production (730.5 million tonnes) and productivity (3.39 tons $\mathrm{ha}^{-1}$ ) (USDA 201819). Wheat also contributed more calories (20 percent) and protein to the world's diet than any other food crop. Now a days availability of wheat has increased from about $79 \mathrm{~g}$ capita $^{-1}$ day $^{-1}$ to more than $185 \mathrm{~g} \mathrm{capita}^{-1}$ day $^{-1}$ despite the doubling of the population since
1961 (Bhardwaj et al., 2010). Thus the global challenge for wheat nutrition is to increase grain yield while maintaining its protein (Tilman et al., 2002). Wheat yield and its quality depend upon the environment, genotype, and their interactions. Low soil fertility, especially nitrogen $(\mathrm{N})$ deficiency, is one of the major constraints limiting wheat production in India especially for high potential wheat varieties. Inadequate supply of available $\mathrm{N}$ frequently results in plants that have slow growth, low protein levels, poor yield of low-quality products, and inefficient 
water use. Therefore, the application of nitrogen fertilizer at the right rate and time is vital for the enhancement of crop productivity and soil fertility. High levels of $\mathrm{N}$ supply results in higher protein content, but increased efficiency of utilization is realized when the concentration in the kernels increases and grain yield remains stable (Ortiz Monasterio et al., 1997). However, increased fertilizer especially nitrogen for obtaining higher yield has led to another problem of lodging in wheat under irrigated conditions. Lodging resulted in reduced wheat yield as well as lowered the quality of the final product and an increase in disease severity is the other detrimental effect of lodging. It has been estimated that losses may occur around 8.3\% of the total wheat production due to lodging (Tripathi et al., 2004).

Since information on the choice of a dose of nitrogen fertilizer as well as plant growth regulators (PGR's) for wheat varieties with high potential is scanty, an attempt has been taken to find out the standardization of various doses of $\mathrm{N}$ for enhancing the productivity of wheat while reducing lodging.

\section{Materials and Methods}

The experiment was conducted at the research farm of Bihar Agricultural University, Sabour during the rabi season of 2019-20.The soil was sandy loam having organic carbon $(0.55 \%)$ with $\mathrm{pH}$ (7.23), available nitrogen (154.11 kg ha $\left.{ }^{-1}\right)$, available phosphorus $(24.45$ $\left.\mathrm{kg} \mathrm{ha}^{-1}\right)$ and available potassium $(184.46 \mathrm{~kg}$ $\left.\mathrm{ha}^{-1}\right)$. The experiment consists of ten treatments viz: $\mathrm{T}_{1}$ - control (no fertilizer used), $\mathrm{T}_{2^{-}} 50 \%$ recommended dose of fertilizer $\left(\mathrm{RDF}=150 \mathrm{~kg} \mathrm{~N} \mathrm{ha}^{-1}\right)$ of $\mathrm{N}$ i.e. $75 \mathrm{~kg} \mathrm{~N} \mathrm{ha}^{-1}$, $\mathrm{T}_{3^{-}}-75 \% \mathrm{RDF}$ of $\mathrm{N}, \mathrm{T}_{4^{-}}-100 \% \mathrm{RDF}$ of $\mathrm{N}, \mathrm{T}_{5^{-}}$ $125 \%$ RDFof $\mathrm{N}, \mathrm{T}_{6^{-}} 150 \% \mathrm{RDF}$ of $\mathrm{N}, \mathrm{T}_{7^{-}}$ 100\% RDF of NPK i.e. 150: 60: 40 N:P: K kg ha $^{-1} \cdot \mathrm{T}_{8^{-}} 125 \%$ RDF of $\mathrm{N}$ with PGRs spray (at first node and boot leaf stage (45 and 65 DAS respectively)), $\mathrm{T}_{9^{-}} 150 \% \mathrm{RDF}$ of $\mathrm{N}$ with PGRs spray (at first node and boot leaf stage) and $\mathrm{T}_{10^{-}} 150 \% \mathrm{RDF}$ of NPK with PGRs (at first node and boot leaf stage).The experiment was laid out in a randomized block design with three replications. Wheat cultivar DBW187 (Karan vandana) was sown on $25^{\text {th }}$ November 2019 and harvested on 4 April 2020. Wheat seed @ 100 kg ha ${ }^{-1}$ was sown at a row to row spacing of $20 \mathrm{~cm}$. Urea, DAP and MOP were used as the source of nitrogen, phosphorus and potash respectively. The crop received two uniform irrigations at crown root initiation and flowering stage.

\section{Lodging observation}

Lodging score: to score lodging, the percentage area of the plot that lodged was estimated and the angle of the stem was estimated (Rebetzke et al., (2011).

$$
\text { Lodging score }=\frac{\% \text { plot are lodged } \mathrm{x} \text { angle of lodging from vertical }}{90}
$$

\section{Results and Discussion}

Data presented in figure 1 revealed that increment in the rate of nitrogen fertilizer increased the lodging of the wheat crop. The lodging of the crop occurred after the flowering which was associated with the high nitrogen levels, onset of rainfall and highspeed wind. The range of the lodging score varied from 3.87 to 16.63 . Maximum lodging score was observed in treatment $\mathrm{T}_{6}: 150 \%$ RDF of $\mathrm{N}$ (16.63) while no lodging occurred in treatment control $\left(\mathrm{T}_{1}\right)$. Application of plant growth regulator (Chloromequat chloride $0.2 \%$ and tebuconazole $0.1 \%$ ) at first node and boot leaf stage reduced the crop lodging in treatment $\mathrm{T}_{8}$ (3.87) and $\mathrm{T}_{9}$ (6.80) as compared to treatment $\mathrm{T}_{5}(10.53)$ and $\mathrm{T}_{6}$ (16.63) in which no plant growth regulators were applied. 
Table.1 Effect of nitrogen levels and plant growth regulators on the yield of wheat

\begin{tabular}{|l|l|c|c|c|c|}
\hline Treatment & Grain q ha & Straw q ha & Biological q ha & HI \\
\hline $\mathbf{T}_{\mathbf{1}}$ & Control & 28.15 & 39.45 & 67.60 & 0.42 \\
\hline $\mathbf{T}_{\mathbf{2}}$ & 50\% RDF of N & 32.97 & 43.33 & 76.30 & 0.43 \\
\hline $\mathbf{T}_{\mathbf{3}}$ & 75\% RDF of N & 36.74 & 46.79 & 83.53 & 0.44 \\
\hline $\mathbf{T}_{\mathbf{4}}$ & 100\% RDF of N & 38.96 & 50.58 & 89.55 & 0.44 \\
\hline $\mathbf{T}_{\mathbf{5}}$ & 125\% RDF of N & 40.19 & 53.68 & 93.87 & 0.43 \\
\hline $\mathbf{T}_{\mathbf{6}}$ & 150\% RDF of N & 41.45 & 53.30 & 94.75 & 0.44 \\
\hline $\mathbf{T}_{\mathbf{7}}$ & 100\% RDF of NPK & 49.23 & 63.85 & 113.07 & 0.44 \\
\hline $\mathbf{T}_{\mathbf{8}}$ & $\begin{array}{l}\text { 125\% RDF of N with } \\
\text { growth regulator }\end{array}$ & 43.06 & 52.02 & 95.08 & 0.45 \\
\hline $\mathbf{T}_{\mathbf{9}}$ & $\begin{array}{l}\text { 150\% RDF of N with } \\
\text { growth regulator }\end{array}$ & 44.41 & 55.43 & 99.84 & 0.45 \\
\hline $\mathbf{T}_{\mathbf{1 0}}$ & $\begin{array}{l}\text { 150\%RDF of NPK with } \\
\text { growth regulator }\end{array}$ & 51.71 & 65.38 & 117.09 & 0.44 \\
\hline $\mathbf{S . E m . ( \pm )}$ & & 1.29 & 1.48 & 2.45 & 0.01 \\
\hline $\mathbf{C D}(\mathbf{p = 0 . 0 5 )}$ & 3.84 & 4.40 & 7.27 & 0.02 \\
\hline
\end{tabular}

Fig.1 Effect of nitrogen levels and growth regulators on lodging score of wheat

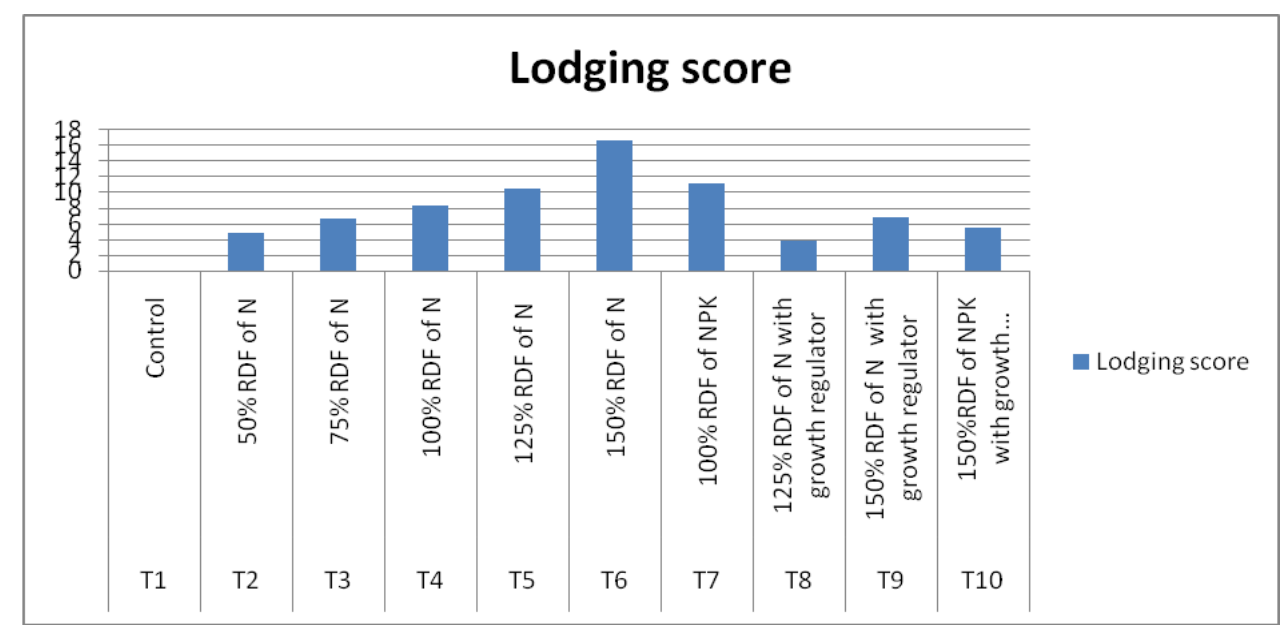

\section{Effect on grain yield of Wheat}

Highest grain yield was recorded in treatment $\mathrm{T}_{10}\left(51.71 \mathrm{q} \mathrm{ha}{ }^{-1}\right)$ which was significantly higher than all the treatments but statistically at par with treatment $\mathrm{T}_{7}\left(49.23 \mathrm{q} \mathrm{ha}^{-1}\right)$. A similar trend was observed with straw and biological yield also in which treatment $\mathrm{T}_{10}$ (65.38 $\mathrm{q} \mathrm{ha}^{-1}$ and $117.09 \mathrm{q} \mathrm{ha}^{-1}$ respectively) was significantly higher than all the treatment except treatment $\mathrm{T}_{7}\left(63.85\right.$ and $113.07 \mathrm{q} \mathrm{ha}^{-}$
${ }^{1}$ respectively). However, the highest harvest index was found in treatment $\mathrm{T}_{8}$ and $\mathrm{T}_{9}(0.45$ in both) and the minimum was recorded in control: $\mathrm{T}_{1}(0.42)$. The increase in yield might be due to increased growth and yield attributing characters and higher photosynthesis activities at a higher fertility level. Balanced nutrition throughout various growth stages of a plant enables it to assimilate sufficient photosynthetic products and enhanced dry matter accumulation. 
Minimum losses due to lodging were observed in treatments supplied with chlormequat chloride $0.2 \%$ + tebuconazole $0.1 \%$ at the first node and boot leaf stage which protected the plants against lodging. The observations confirmed with the findings of Shekoofa and Emam (2008).Tebuconazole application resulted in increased leaf area and delayed senescence of leaves which is a major supporter of photosynthates from source to sink (grain) and this resulted in higher grain yield. It is also a well-known fact that with the increasing level of fertilizer application, the intensity and nutrient supply capacity of soil also increased (Wang et al., 2012).

Based on summarized results, it can be concluded that spray of PGRs effectively reduced the lodging of wheat and enhanced grain and straw yield of the plants. The highest grain and straw yield was recorded with 150\% RDF of NPK i.e. 225:90:60 N:P:K $\mathrm{kg}$ ha $^{-1}$ with chlormequat chloride $0.2 \%+$ tebuconazole $0.1 \%$ at 45 and 65 DAS of sowing.

\section{References}

Dwivedi SK, Meshram MR, Pandey N (2014). Response of customized fertilizer on wheat (Triticumaestivum) under Chhattisgarh condition. The Bioscan 9(4):1509-1512.

Ortiz-Monasterio R, Sayre KD, Rajaram S, McMahon M (1997). Genetic progress in wheat yield and nitrogen use efficiency under four nitrogen rates. Crop Science, 37(3): 898-904.

Shekoofa A, Emam Y (2008). The increase of wheat grain yield due to the application of cycocel results from the increase of the number of spikes per square meter. Journalof Agriculture Science and technology(10):101-108.

Tilman D, CassmanKG, Matson PA, Naylor R, and Polasky S (2002) Agricultural sustainability and intensive production practices. Nature 418:671-677.

Toyota M, Shiotsu F, Bian J, Morokuma M, Kusutani A (2010)Effects of Reduction in Plant Height Induced by Chlormequat on Radiation Interception and Radiation-Use Efficiency in Wheat in Southwest Japan. Plant Production Science 13(1):67-73.

Tripathi SC, Sayreb KD, Kaul JN, NarangcRS (2004) Lodging behavior and yield potential of spring wheat (Triticumaestivum L.): effects of ethephon and genotypes. Field crops research 87(2-3):207-220.

Wang Q, Li F, Zhang E, Li G, Vance M (2012) The effects of irrigation and nitrogen application rates on yield of spring wheat (longfu-920), and water use efficiency and nitrate nitrogen accumulation in soil. Australian journal of crop science 6(4):662-672.

\section{How to cite this article:}

Aditya Shri, Seema, Sushant and Mahendra Singh. 2020. Effect of Different Levels of Nitrogen and Plant Growth Regulators on Lodging and Yield of Wheat (Triticum aestivum L.). Int.J.Curr.Microbiol.App.Sci. 9(12): 3358-3361. doi: https://doi.org/10.20546/ijcmas.2020.912.400 